\title{
Economic relationships of brushpiles, forage production, and California quail hunting
}

\author{
W. PAUL GORENZEL, SONKE A. MASTRUP, AND E. LEE FITZHUGH
}

\begin{abstract}
Harvesting trees for nirewood in the oak hardwood rangelands of the western Sierra Nevada foothills creates slash that may be burned to improve livestock forage production or piled into brushpiles for wildlife. The economics of these actions are undocumented. We observed a firewood harvest that created 378 brushpiles averaging $13.6 \mathrm{~m}^{2}$ and $1.3 \mathrm{~m}$ high, and resulted in a forage loss of $1,807 \mathrm{~kg}$ dry weight, equivalent to 4.4 AUM. We projected the present net value of 5 management options concerning the removal or retention of brushpiles during a 15-year period. Inputs included revegetation of burned-brushpile sites, annual forage production on areas with the oak canopy removed, burning and reseeding costs, and income derived from cattle grazing and quail hunting. The options were: $(A)$ burning all brushpiles and reseeding the burned sites; (B) option A without reseeding; (C) burning 235 brushpiles and reseeding, leaving 23 brushpiles/ha for quail; (D) option C without reseeding; (E) leaving all brushpiles. All but option B were economically feasible at $a 4 \%$ interest rate; at an $8 \%$ interest rate, only options C-E were profitable. After 15 years, the accumulated returns per hectare at $4 \%$ for options A-E were $\$ 11.67, \$-3.97, \$ 32.43, \$ 22.29$, and $\$ 23.35$, respectively, and at $8 \%, 5-17.35,5-25.74,58.58,53.02$, and $\$ 17.98$, respectively.
\end{abstract}

Key Words: Callipepla californica, canopy removal, fee hunting, firewood cutting, hardwood rangelands, oaks, Quercus.

Hardwood rangelands comprise 3.9 million ha $(25 \%)$ of the forest land in California and produce about $25 \%$ of the total forage available in California (USDA 1972). Grazing by cattle and sheep has been the primary use of hardwood rangelands. Bolsinger (1988) estimated that livestock grazed on 1.2 million ha (60\%) of the hardwood range dominated by oaks (Quercus spp.) in the early 1980 's. Rangeland improvements from 1945 to 1973 reduced the area of oak-dominated hardwoods by about 360,000 ha (Bolsinger 1987). Most oak-woodland owners cite increased forage production as an important reason for cutting oaks (Fortmann and Huntsinger 1987). However, declines in the profitability of the livestock industry forced some ranchers to seek income through firewood cutting and fee hunting. In the past the sale of firewood helped offset the costs of conversion, but recently the income from the sale of firewood alone has become an incentive.

Brush and tree removal to improve forage production or for firewood can reduce California quail (Callipepla californica) habitat. Because adult California quail do not like to forage any farther than $15 \mathrm{~m}$ into the open (Sumner 1935:194), a clearing as small as 1 ha will remain mostly unused if no brush cover is present. Leaving brushpiles (BP) benefits quail by replacing some of the natural cover that was removed or by creating cover where none previously existed (Leopold 1977). Our objectives were to estimate the costs and benefits of keeping or removing BP and to provide a framework for future analyses.

\footnotetext{
Senior, second, and third authors are staff research associate, post graduate research assistant, and extension wildlife specialist, respectively, Dep. of Wildlife and Fisheries Biology, University of California, Davis 95616. The authors thank $M$ Connor, J. Du Bruile, M. George, R. Schmidt, and an anonymous reviewer for manuscript review, and T. Fisher for firewood harvest area calculations.

This study was partially funded by the Renewable Resources Extension Act, S/L 86-87, Project No. J-620357-21067-7.

Manuscript accepted 31 May 1990
}

\section{Study Area}

Three pastures with BP, Scott 14 (S14), Campbell 11 (C11), and Haworth 7 (H7), resulted from clearing operations during the mid-1970's to early 1980's at the University of California Sierra Foothill Range Field Station (SFRFS) in Yuba County. Classified as blue oak ( $Q$. douglasii) woodland and blue oak-digger pine (Pinus sabiniana) (Mayer and Laudenslayer 1988), the area was representative of western Sierra Nevada foothills. Dominant trees included blue oak, interior live oak ( $Q$. wislizenii), valley oak ( $Q$. lobata), and digger pine. Elevation ranged from about 140 to $300 \mathrm{~m}$.

Before clearing, tree densities ranged from 120 to $450 / \mathrm{ha}$. Clearing removed shrub cover for quail and reduced tree density to between 25 and 100/ha. The cleared areas were 20 to 45 ha and were dominated by annual grasses (bromes, Bromus spp.; fescues, Vulpia spp.; wild oats, Avena spp.) and forbs (filarees, Erodium spp.; clovers, Trifolium spp.), with scattered BP or stands of trees. Brushpiles on $\mathrm{H} 7$ were burned in December 1985 and reseeded shortly thereafter with a clover and grass seed mix. Brushpiles on S14 and C11 were burned in January 1986 but were not reseeded until mid-October 1986, 9 to 9.5 months later.

A firewood harvest occurred from October 1986 to February 1987 on a fourth, previously uncut area, the Schubert pasture. This area lacked a well-developed shrub component essential for quail cover. Wood cutters removed the oak canopy on 7 separate plots within the 73-ha pasture. Slash from the felled trees was piled to create BP.

\section{Methods}

At each harvested plot on the Schubert pasture we mapped the outer boundary and computed area; measured the diameter of all stumps; measured the height and calculated the basal area of each BP. As most BP were circular or elliptical in nature, we measured length $(L)$ and width $(W)$ and computed area $(A)$ as $(3.14)(R)^{2}$, where $R=(L+W) / 4$.

In June 1986 and July 1987 , one observer estimated the percent herbaceous-ground cover at burned-BP sites using the plant cramming technique of Hays et al. (1981). We recorded the presence or absence of thistles (Silybum marianum and Carduus tenuiflorus) at each burned site. Thistles are considered invasive and are unpalatable to cattle (M. Connor, SFRFS superintendent, pers. commun.). Brushpiles are commonly burned on SFRFS to remove thistles growing in and around them.

We calculated forage loss due to coverage by BP (or regained after burning BP) as follows:

$$
[(\operatorname{Ar})(\mathrm{FP})]-[(\mathrm{Ar})(\mathrm{RDM})]=\mathrm{AdFR} \text {, }
$$

where:

Ar or total ground area covered by BP $=[$ (number of BP) (average BP basal area in $\left.\left.\mathrm{m}^{2}\right)\right] /\left(10,000 \mathrm{~m}^{2} /\right.$ ha);

FP = average dry forage production in $\mathrm{kg} / \mathrm{ha}$ at the end of the growing season;

$\mathrm{RDM}=$ residual dry matter in $\mathrm{kg} / \mathrm{ha}$ to remain after grazing;

AdFR = adjusted amount of forage removed by BP in $\mathrm{kg} / \mathrm{ha}$. 
We used Jansen (1987) and Kay (1987) for estimates of FP after removal of the tree canopy on SFRFS and Clawson et al. (1982) for RDM and AUM forage consumption values. We calculated total dollar value of forage loss as $\mathrm{L}=(\mathrm{AdFR} / \mathrm{AUM}) \mathrm{V}$, where $\mathrm{AUM}=$ forage equivalent of 1 animal unit month in $\mathrm{kg}$, and $\mathrm{V}=$ dollar value of $1 \mathrm{AUM}$.

We compared the present net worth or value of different management options according to Olson (1986). We calculated the accumulated present values (APV) as follows:

$$
\begin{aligned}
\text { APV } & =\sum_{i=0}^{n}\left[\left(C_{n}+R_{n}\right)\left(1 /(1+I)^{n}\right)\right], \\
\text { where: } & \\
& C=\text { costs; } \\
& R=\text { net income; } \\
n & =\text { number of years into the future; } \\
& I=\text { discount or interest rate. }
\end{aligned}
$$

We illustrated the calculations at a $4 \%$ interest rate and evaluated the sensitivity of the different options to changes in interest rates from 4 to $8 \%$. The management options were: (A) burning all BP and reseeding the burned sites to improve livestock forage production; (B) option A without reseeding; (C) burning 235 BP and reseeding, but leaving $143 \mathrm{BP}(24.7 \mathrm{BP} / \mathrm{ha}$ ) for quail; (D) option C without reseeding; (E) leaving all BP. Field station personnel provided costs for supplies and labor estimates. We valued labor at the California minimum wage rate of $\$ 4.25 /$ hour. Fee hunting for quail was valued at $\$ 2.10 / \mathrm{ha} / \mathrm{yr}$ (Passof et al. 1985).

\section{Results}

\section{Firewood Cutting}

\begin{tabular}{|c|c|c|c|c|c|c|}
\hline Plot & $\begin{array}{l}\text { Hec- } \\
\text { tares }\end{array}$ & $\begin{array}{c}\text { No. } \\
\text { of } \\
\text { trees } \\
\text { cut }\end{array}$ & $\begin{array}{c}\text { Stump } \\
\text { diameter } \\
(\mathrm{cm}) \\
(\bar{X} \pm \mathrm{SE})\end{array}$ & $\begin{array}{c}\text { Number } \\
\text { of } \\
\text { brushpiles }\end{array}$ & $\begin{array}{c}\text { Brushpile } \\
\text { basal area } \\
\left(\mathrm{m}^{2}\right) \\
(\bar{X} \pm \mathrm{SE})\end{array}$ & $\begin{array}{c}\text { Brushpile } \\
\text { height } \\
(\mathrm{m}) \\
(\bar{X} \pm \mathrm{SE})\end{array}$ \\
\hline 1 & 0.6 & 100 & $32.2 \pm 1.2$ & 39 & $13.8 \pm 1.4$ & $1.1 \pm 0.03$ \\
\hline 2 & 0.7 & 325 & $22.9 \pm 0.7$ & 52 & $15.8 \pm 1.4$ & $1.3 \pm 0.03$ \\
\hline 3 & 0.4 & 105 & $26.6 \pm 1.2$ & 35 & $9.9 \pm 1.0$ & $1.3 \pm 0.04$ \\
\hline 4 & 0.8 & 182 & $28.5 \pm 1.1$ & 72 & $11.2 \pm 0.8$ & $1.2 \pm 0.03$ \\
\hline 5 & 0.9 & 118 & $33.3 \pm 1.1$ & 58 & $9.6 \pm 0.7$ & $1.2 \pm 0.02$ \\
\hline 6 & 1.1 & 292 & $26.2 \pm 0.8$ & 53 & $16.8 \pm 1.4$ & $1.4 \pm 0.03$ \\
\hline 7 & 1.2 & 227 & $28.2 \pm 1.0$ & 69 & $16.8 \pm 1.4$ & $1.3 \pm 0.02$ \\
\hline
\end{tabular}

Firewood cutters cleared 5.8 ha on 7 plots that averaged 0.8 ha each (Table 1). They cut 1,349 trees ranging in stump diameter

Table 1. Tree and brushple statistics from 7 plots cleared by firewood cutters on the Schubert pasture, Sierra Foothill Range Field Station, Yuba County, Calif.

from 2.5 to $95.2 \mathrm{~cm}$. The woodcutters created $378 \mathrm{BP}$; basal areas ranged from 2.2 to $72.4 \mathrm{~m}^{2}$ and averaged $13.6 \mathrm{~m}^{2}$. Heights ranged from 0.6 to $1.8 \mathrm{~m}$ and averaged $1.3 \mathrm{~m}$. BP densities averaged $65.2 /$ ha.

\section{Burned Brushpile Site Revegetation}

We examined 44 burned BP on the S14 and $\mathrm{C} 11$ pastures and 23 burned $\mathrm{BP}$ on the $\mathrm{H} 7$ pasture. Herbaceous vegetation was present by the end of the first growing season after burning on all sites, even though none of the burned sites on $\mathrm{S} 14$ or $\mathrm{C} 11$ were reseeded (Table 2). About $60 \%$ of the burned sites on $\mathrm{S} 14$ and $\mathrm{Cl} 11$ were in the lowest cover class compared with $30 \%$ on the reseeded sites on H7. Otherwise there was little difference between the unseeded and reseeded sites. After the second growing season, all burned sites showed increased cover. On the now reseeded $\mathrm{S} 14$ and $\mathrm{C} 11$ sites, $89 \%$ were in the $51-100 \%$ cover classes compared to $91 \%$ on $\mathrm{H} 7$. There was no difference between the 2 groups in the 3 greatest
Table 2. Number of burned brushpiles on 3 pastures (S14, C11, H7) grouped according to cover class (percent of area covered by herbaceous vegetation) during 2 sampling periods, June 1986 and July 1987, on the Sierra Foothill Range Field Station, Yuba County, Calif.

\begin{tabular}{lccccc}
\hline & \multicolumn{5}{c}{ Location } \\
\cline { 2 - 3 } \cline { 2 - 3 } \cline { 5 - 6 } \% Cover class & \multicolumn{2}{c}{ S14 and C11 } & & H7 \\
\cline { 2 - 3 } \cline { 5 - 6 } & 1986 & 1987 & & 1986 & 1987 \\
\hline $0-25$ & 26 & 0 & & 7 & 0 \\
$26-50$ & 10 & 5 & & 11 & 2 \\
$51-75$ & 6 & 9 & & 3 & 6 \\
$76-100$ & 2 & 30 & & 2 & 15 \\
\hline
\end{tabular}

cover class frequencies at the end of the second growing season $\left(X^{2}\right.$ $=0.34, \mathrm{df}=2, \mathrm{p}=0.84$ ). In comparison, examination of herbaceous cover on sites adjacent to burned BP indicated all would be in the 76 to $100 \%$ cover class.

Most burned sites had thistle, with only minor changes in frequency occurring from the first growing season to the second, from 41 to 39 of 44 sites on $S 14$ and C11, and from 20 to 18 of 23 sites on H7, respectively. Although we did not quantify biomass or percent ground cover for individual grass or forb species, qualitative field observations showed an obvious difference in the abundance of thistle on $\mathrm{S} 14$ and $\mathrm{C} 11$ compared with $\mathrm{H} 7$. Thistle was a major, if not dominant, component of the reestablished herbaceous cover on $\mathrm{S} 14$ and $\mathrm{Cl} 1$ burned sites. Although present at 18 to 20 burned sites on $\mathrm{H} 7$, thistle was a major component at only 1 site; at the others it was represented by scattered plants.

\section{Canopy Removal, Forage, and Brushpile Relationships}

Two studies on SFRFS examined changes in forage production after removal of the oak canopy. Jansen (1987) found that removal of 25,50 , and $75 \%$ of blue oak canopies increased forage production during a 7 -year period $46 \%$ over tree-covered plots to an average of $4,215 \mathrm{~kg} / \mathrm{ha}$. During a 21 -year period, Kay (1987) noted an average $45 \%$ increase in forage on plots with top-killed trees. After year 15, forage production decreased to the levels of treecovered and open-grassland plots.

With an average basal area of $13.6 \mathrm{~m}^{2}$, the $378 \mathrm{BP}$ on the Schubert pasture covered 0.51 ha. Assuming a forage production of $4,215 \mathrm{~kg} / \mathrm{ha}, 2,150 \mathrm{~kg}$ of forage was covered by BP. Management practices on SFRFS were based on Clawson et al. (1982) and left a minimum of $672 \mathrm{~kg} /$ ha of residual dry matter after grazing. Forage loss adjusted to account for residual dry matter resulted in $1,807 \mathrm{~kg}$ of forage unavailable to livestock. At a forage consumption rate of $3 \%$ of body weight per day (Clawson et al. 1982) a mature $454 \mathrm{~kg}$ cow eats $13.6 \mathrm{~kg}$ of forage per day, or $408 \mathrm{~kg}$ per month, equivalent to 1 animal unit month (AUM). Calculated forage loss on Schubert from 378 BP was 4.4 AUM. Conversely, if $378 \mathrm{BP}$ were burned, 4.4 AUM would be regained. Following the above procedure, if $235 \mathrm{BP}$ were burned leaving $143 \mathrm{BP}, 1,134 \mathrm{~kg}$ of forage equivalent of $2.8 \mathrm{AUM}$ would become available to livestock.

\section{Economic Analyses}

For the economic comparisons below, the 1,807 and $1,134 \mathrm{~kg}$ of forage mentioned above are assumed palatable to cattle and available only if the burned areas are reseeded, as is the normal SFRFS practice.

Although Jansen (1987) and Kay (1987) recorded significant forage increase starting the second growing season after canopy removal, logs and slash were removed (not burned on site) from their plots in a manner that minimized soil disturbance. Our cover surveys (Table 2) of reseeded burned BP on $\mathrm{H} 7$ suggested most sites did not achieve the highest cover class rating until the end of 
Table 3. Comparison of costs (5) for burning and reseeding brushpiles, and the value of income derived from forage increases and quail hunting for 5 different management options (A - E) on 5.8 ha, Sierra Foothill Range Field Station, Yuba County, Calif. Positive values represent income, negative values represent costs. Values for forage production and quail hunting are not discounted to present values (see Table 4).

\begin{tabular}{|c|c|c|c|c|c|}
\hline \multirow[b]{2}{*}{ Activity } & \multicolumn{5}{|c|}{ Option } \\
\hline & A & B & C & D & $\mathbf{E}$ \\
\hline $\begin{array}{l}\text { Burning brushp } \\
\text { Labor }^{\mathbf{a}} \\
\text { Materials }^{\mathrm{b}}\end{array}$ & $\begin{array}{r}\$-372.52 \\
-189.00\end{array}$ & $\begin{array}{r}\text { S-372.52 } \\
-189.00\end{array}$ & $\begin{array}{l}\$ 231.59 \\
-117.50\end{array}$ & $\begin{array}{r}\text { S-231.59 } \\
-117.50\end{array}$ & $\begin{aligned} \text { S } 0 \\
0\end{aligned}$ \\
\hline $\begin{array}{l}\text { Reseeding } \\
\text { Labor }^{\mathrm{c}} \\
\text { Materials }^{\mathrm{d}}\end{array}$ & $\begin{array}{l}-69.85 \\
-18.89\end{array}$ & $\begin{array}{l}0 \\
0\end{array}$ & $\begin{array}{r}-43.42 \\
-11.71\end{array}$ & $\begin{array}{l}0 \\
0\end{array}$ & $\begin{array}{l}\mathbf{0} \\
\mathbf{0}\end{array}$ \\
\hline $\begin{array}{l}\text { Forage product } \\
\text { Year } 1^{\circ} \\
\text { Years } 2-15^{f}\end{array}$ & $\begin{array}{l}49.50 \\
66.00 / \mathrm{yr}\end{array}$ & $\begin{array}{l}37.12 \\
49.50 / \mathrm{yr}\end{array}$ & $\begin{array}{l}31.50 \\
42.00 / \mathrm{yr}\end{array}$ & $\begin{array}{l}23.63 \\
31.50 / \mathrm{yr}\end{array}$ & $\begin{array}{l}0 \\
0\end{array}$ \\
\hline $\begin{array}{l}\text { Quail hunting } \\
\text { Years 1-15 }\end{array}$ & 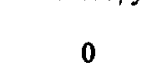 & 0 & $12.18 / \mathrm{yr}$ & $12.18 / \mathrm{yr}$ & $12.18 / \mathrm{yr}$ \\
\hline
\end{tabular}

"Based on estimate of 16 hours for 69 brushpiles (M. Connor. SFRFS superintendent, pers. commun.) at $\$ 4.25 / \mathrm{hr}$.

Based on $1.9 \mathrm{~L}$ of diesel fuel per brushpile at \$0.26/L (M. Connor, pers. commun.).

- Based on estimate of 3 hours for 69 brushpiles (M Connor pers. commun.) at \$4.25/hr.

dBased on seed requirements at $9.2 \mathrm{~kg}$ supplied at rate of $17.9 \mathrm{~kg} / \mathrm{ha}$, at a cost of $\$ 2.05 / \mathrm{kg}$ (M. Connor, pers. commun.)

Based on seed requirements at $9.2 \mathrm{~kg}$ supplied at rate of $17.9 \mathrm{~kg} / \mathrm{ha}$, at a cost of $\$ 2.05 / \mathrm{kg}$ (M. Connor, pers. commun.).

'Based on $75 \%$ of potential forage production for reseeded sites, an additional $25 \%$ reduction for unseeded sites, and $\$$.
'Based on $100 \%$ of potential forage production for reseeded sites, $75 \%$ production for unseeded sites, and \$15/AUM.

${ }^{*}$ Based on net income derived from quail hunting at $\$ 2.10 / \mathrm{ha} / \mathrm{yr}$ (Passof et al. 1985). No income derived under plans A or B.

the second growing season. We therefore assumed $75 \%$ forage production during year 1 and $100 \%$ forage production for years 2 through 15. Surveys on S14 and C11 (not reseeded until after the first growing season) showed a similar pattern of revegetation at the end of the second growing season, but dominance by thistles. For the comparisons below, forage production on sites that were burned but not reseeded was reduced an additional $25 \%$ relative to reseeded sites to reflect dominance by thistles.

We assumed quail did not benefit from canopy removal and the burning of all BP in options A and B given the lack of brush cover. Hunters would perceive such areas as unsuitable habitat for hunting or leasing. The value of quail hunting was not reduced with the removal of $235 \mathrm{BP}$ in options $\mathrm{C}$ and $\mathrm{D}$ compared to option $\mathrm{E}$. We assumed hunters would perceive the remaining $24.7 \mathrm{BP} /$ ha as proper habitat management as suggested by existing literature (e.g., Fitzhugh 1983).

The rankings for both initial costs and yearly income were A $>$ B $>$ C $>$ D $>$ E (Table 3). At a $4 \%$ discount rate, a positive APV was first achieved for options $A$ and $C-E$ in years $14,10,11$, and 1 , respectively (Table 4). Option $B$ did not achieve positive returns during the 15-year period. Accumulated present values after 15 years ranked $\mathrm{C}>\mathrm{E}>\mathrm{D}>\mathrm{A}>\mathrm{B}$. The $\mathrm{APV} /$ ha for options $\mathrm{A}-\mathrm{E}$ were
$\$ 11.67, \$-3.97, \$ 32.43, \$ 22.29$, and $\$ 23.35$, respectively.

The sensitivity analysis of increasing the discount rates from 4 to 8\% indicated: (1) all options become less profitable with increasing discount rates; (2) option $A$ became unprofitable at discount rates exceeding about $5.5 \%$; (3) option $E$ was robust to increasing rates, with a decrease in APV/ ha of only \$5.37; (4) option E was the most profitable plan at interests rates exceeding about $5.5 \%$ (Table 5). The APV/ ha for options A-E at an $8 \%$ discount rate were $\$-17.35$, $\$-25.74, \$ 8.58, \$ 3.02$, and $\$ 17.98$, respectively.

Table 5. Accumulated present values (S) of 5 management options (A-E) at different discount rates after 15 years.

\begin{tabular}{lrrrrr}
\hline \hline & \multicolumn{5}{c}{ Discount rate (\%) } \\
\cline { 2 - 6 } Option & \multicolumn{1}{c}{4} & \multicolumn{1}{c}{5} & \multicolumn{1}{c}{6} & \multicolumn{1}{c}{7} & \multicolumn{1}{c}{8} \\
\hline A & 67.69 & 19.08 & -24.82 & -64.57 & -100.63 \\
B & -23.05 & -59.53 & -92.42 & -122.27 & -149.31 \\
C & 188.09 & 148.14 & 112.74 & 79.41 & 49.78 \\
D & 129.29 & 96.78 & 67.71 & 41.37 & 17.49 \\
E & 135.43 & 126.42 & 118.30 & 110.91 & 104.26 \\
\hline
\end{tabular}

Table 4. Yearly and accumulated present values (S) at a $4 \%$ discount rate for 5 management options (A - E) during a 15-year period on the Sierra Foothill Range Field Station, Yuba County, Calif.

\begin{tabular}{|c|c|c|c|c|c|c|c|c|c|c|}
\hline \multirow[b]{2}{*}{ Year } & \multicolumn{5}{|c|}{ Present value of expected net returns } & \multicolumn{5}{|c|}{ Accumulated present value } \\
\hline & A & $\mathbf{B}$ & $\mathbf{C}$ & D & $\mathbf{E}$ & $\mathbf{A}$ & B & $\mathrm{C}$ & $\mathbf{D}$ & $\mathbf{E}$ \\
\hline 0 & -650.26 & -561.52 & -404.22 & -349.09 & 0 & -650.26 & -561.52 & -404.22 & -349.09 & 0 \\
\hline 1 & 47.59 & 35.69 & 42.00 & 34.43 & 11.71 & -602.67 & -525.83 & -362.22 & -314.66 & 11.71 \\
\hline 2 & 61.02 & 45.77 & 50.09 & 40.39 & 11.26 & -541.65 & -480.06 & -312.13 & -274.27 & 22.97 \\
\hline 3 & 58.67 & 44.00 & 48.17 & 38.83 & 10.83 & -482.98 & -436.06 & -263.96 & -235.44 & 33.80 \\
\hline 4 & 56.42 & 42.31 & 46.31 & 37.34 & 10.41 & -426.56 & -393.75 & -217.65 & -198.10 & 44.21 \\
\hline 5 & 54.25 & 40.68 & 44.53 & 35.90 & 10.01 & -372.31 & -353.07 & -173.12 & -162.20 & 54.22 \\
\hline 6 & 52.16 & 39.12 & 42.82 & 34.52 & 9.63 & -320.15 & -313.95 & -130.30 & -127.68 & 63.85 \\
\hline 7 & 50.15 & 37.62 & 41.17 & 33.19 & 9.26 & -270.00 & -276.33 & -89.13 & -94.49 & 73.11 \\
\hline 8 & 48.23 & 36.17 & 39.59 & 31.92 & 8.90 & -221.77 & -240.16 & -49.54 & -62.57 & 82.01 \\
\hline 9 & 46.37 & 34.78 & 38.07 & 30.69 & 8.56 & -175.40 & -205.38 & -11.47 & -31.88 & 90.57 \\
\hline 10 & 44.59 & 33.44 & 36.60 & 29.51 & 8.23 & -130.81 & -171.94 & 25.13 & -2.37 & 98.80 \\
\hline 11 & 42.87 & 32.16 & 35.20 & 28.37 & 7.91 & -87.98 & -139.78 & 60.33 & 26.00 & 106.71 \\
\hline 12 & 41.22 & 30.92 & 33.84 & 27.28 & 7.61 & -46.72 & -108.86 & 94.17 & 53.58 & 114.32 \\
\hline 13 & 39.64 & 29.73 & 32.54 & 26.23 & 7.32 & -7.08 & -79.13 & 126.71 & 79.81 & 121.64 \\
\hline 14 & 38.12 & 28.59 & 31.29 & 25.22 & 7.03 & 31.04 & -50.54 & 158.00 & 105.03 & 128.67 \\
\hline 15 & 36.65 & 27.49 & 30.09 & 24.26 & 6.76 & 67.69 & -23.05 & 188.09 & 129.29 & 135.43 \\
\hline
\end{tabular}




\section{Discussion}

Given the conditions at SFRFS and the assumptions we made, burning all BP to increase forage production for livestock was profitable only at conservative discount rates of less than about $5.5 \%$ and only if the burned BP were reseeded. Leaving all BP for quail management (option E) incurred no initial expenses, thus allowing positive APV starting in year 1. The lower returns of options B and D compared with A and C, respectively, illustrated the beneficial value of reseeding burned BP. The cost savings of not reseeding burned sites was offset by decreased forage production. An integration of cattle and quail management or quail management only (options C-E) gave positive returns during a 15-year period at all interest rates. Despite lower APV than option E at higher discount rates, option $\mathrm{C}$ may be the best management strategy. In areas of moderate to high rainfall such as the Coast Ranges and Sacramento Valley foothills, grazing thins dense grass stands, improving access for California quail and permitting the growth of preferred seed-producing forbs (Leopold 1977:178).

Our surveys suggested that the disturbed ground at the burned BP sites was favorable for germination of thistles and that reseeding soon after burning reduced thistle abundance. Thistle seeds are consumed by California quail (Leopold 1977:241, 243, 244) but apparently are not a preferred food if other forbs, especially legumes, are present. On SFRFS the seed mix used on the burned sites and for range improvements in general included rose clover (Trifolium hirtum). Rose clover is a highly preferred quail food that represented up to $92 \%$ by weight of the fall diet on SFRFS (Kay 1986). Reseeding apparently provides multiple benefits for livestock and quail.

The data and assumptions that were used best apply to the central Sierra Nevada foothills. Local factors and differences between regions must be considered. For example, average forage production and forage response to canopy removal will vary from site to site. Studies in the south-central Sierra Nevada foothills and southern Coast Range found forage production 40-100\% greater under blue oaks than in open grassland and forage yields declined after canopy removal to levels comparable to the less productive open grasslands (Holland 1980). The method of canopy removal can affect forage production. Kay (1987) recorded an average forage increase of $66 \%$ for root-killed trees using a 2,4-D, but only a $45 \%$ increase for top-killed trees. The use of herbicides would increase costs.

Kay (1987) reported a 15-year time limit to forage increases. Time limits for other sites or regions are undocumented. Similarly a decrease in the wildlife value of BP with time is suggested by the popular literature (e.g., Fitzhugh 1983) due to settling and decay. The rate of decay and settling is related to site specific climatic factors and the species of woody materials used in the BP. If a 10-year lifespan is assumed for BP, the order of rankings for plans A-E based on APV at $4 \%$ will not change. However, the APV for plans C-E will decrease to $\$ 151.46, \$ 92.36$, and $\$ 98.80$, respectively.

The presence of BP may affect other wildlife. The California ground squirrel (Spermophilus beecheyi) commonly burrows under and around BP in some regions of California, suggesting BP are a favorable habitat component for squirrels. However, the response of ground squirrels to new BP is not documented. We observed no apparent increase in ground squirrels on the new BP areas on SFRFS. At densities of 8 or more per hectare, ground squirrels can compete with livestock for forage (Fitch and Bentley 1949, Howard et al. 1959). Ground squirrels are quail nest predators; Glading (1938) attributed 30 nests destroyed by ground squirrels from a total of 96 nests found. These losses occurred when ground squirrel density was about 25 squirrels/ha. Brushpiles are attractive to certain nongame birds and may increase deer use of open areas by breaking sight lines and providing hiding cover.
Dollar values of the impacts of BP on other wildlife besides quail are not readily available but may be important in some cases.

Costs and income may vary depending on location. In Texas, gross income from a season hunting lease for bobwhite (Colinus virginianus) ranges from $\$ 1.24$ to $\$ 16.06 /$ ha, with a net of about $\$ 12.35 /$ ha for the higher price (Guthery 1986). For comparison, Passof et al. (1985) listed an average gross income of $\$ 3.09 /$ ha and a net income of $\$ 2.10 /$ ha for quail hunting in California. The price of a hunting lease depends in part on the quality of habitat, the number of birds present, services and facilities offered, the degree of management, and/or the hunter's perception of that management.

We have provided a framework to calculate the amount of forage covered by $\mathrm{BP}$ and to analyze the economics of removing or keeping BP relative to changes in forage production. We applied data obtained on SFRFS to specific cleared areas totalling $\mathbf{5 . 8}$ ha, as an example, although it is unrealistic that hunters would lease such a limited area. We assume most quail hunting leases in California involve hundreds of hectares. Over such large areas, patch cuts for firewood that create BP could be perceived by the hunter as improving the habitat for quail in the entire leased area, possibly resulting in a higher lease price for the entire area. The financial impact of the BP would thus be spread over a greater area than the site-limited changes in forage production that would occur with their removal.

\section{Literature Cited}

Bolsinger, C.L. 1987. Major findings of a statewide resource assessment in California, p. 291-297. In: T.R. Plumb and N.H. Pillsbury (tech. coords.), Proc. Multiple-use of California's Hardwood Resources. USDA Forest Serv. Pacific Southwest Forest and Range Exp. Sta., Berkeley, Calif. Gen. Tech. Rep. PSW-100.

Bolsinger, C.L. 1988. The hardwoods of California timberlands, woodlands, and savannas. USDA Forest Serv. Pacific Northwest Forest and Range Exp. Sta., Portland, Ore. PNW-RB-148.

Clawson, W.J., N.K. McDougald, and D.A. Duncan. 1982. Guidelines for residue management on annual range. Univ. California Div. Agr. Sci. Leafl. 21327.

Fitch, H.S., and J.F. Bentley. 1949. Use of California annual-plant forage by range rodents. Ecology 30:306-321.

Fitzhugh, E.L. 1983. How to increase California quail populations. Univ. California Div. Agr. Sci. Leafl. 21325.

Fortmann, L., and L. Huntsinger. 1987. Managing California's oak woodlands: a sociological study of owners, p. 379-384. In: T.R. Plumb and N.H. Pillsbury (tech. coords.), Proc. Multiple-Use of California's Hardwood Resources. USDA Forest Serv. Pacific Southwest Forest and Range Exp. Sta., Berkeley, Calif. Gen. Tech. Rep. PSW-100.

Glading, B. 1938. Studies on the nesting cycle of the California valley quail in 1937. California Fish \& Game 24:318-340.

Guthery, F.S. 1986. Beef, brush and bobwhites. Quail management in cattle country. CKWRI Press. Kingsville, Tex.

Hays, R.L., C. Summers, and W. Seitz. 1981. Estimating wildlife habitat variables. U.S. Fish and Wildl. Serv. FWS/OBS-81/47.

Holland, V.L. 1980. Effect of blue oak on rangeland forage production in Central California, p. 314-318. In: T.R. Plumb (tech. coord.), Proc. Ecology, Management, and Utilization of California Oaks. USDA Forest Serv. Pacific Southwest Forest and Range Exp. Sta., Berkeley, Calif. Gen. Tech. Rep. PSW-44.

Howard, W.E., K.A. Wagnon, and J.R. Bentley. 1959. Competition between ground squirrels and cattle for range forage. J. Range Manage. $12: 110-115$.

Jansen, H.C. 1987. The effect of blue oak removal on herbaceous production on a foothill site in the Northern Sierra Nevada, p. 343-350. In: T.R. Plumb and N.H. Pillsbury (tech. coord.), Proc. Multiple-Use of California's Hardwood Resources. USDA Forest Serv. Pacific Southwest Forest and Range Exp. Sta., Berkeley, Calif. Gen. Tech. Rep. PSW-100.

Kay, B.L. 1986. Rose clover-a preferred quail food. Trans. West. Sect. Wildl. Soc. 22:39-41. 
Kay, B.L. 1987. Long-term effects of blue oak removal on forage production, forage quality, soil, and oak regeneration, p. 351-357. In: T.R. Plumb and N.H. Pillsbury (tech. coords.), Proc. Multiple-Use of California's Hardwood Resources. USDA Forest Serv. Pacific Southwest Forest and Range Exp. Sta., Berkeley, Calif. Gen. Tech. Rep. PSW-100. Leopold, A.S. 1977. The California quail. Univ. California Press. Berkeley. Mayer, K.E., and W.F. Laudenslayer Jr. (eds.). 1988. A guide to wildlife habitats of California. California Dep. Forest. and Fire Protection. Sacramento

Olson, K.D. 1986. Economics of orchard replacement. Univ. California Div. Agr. and Nat. Resour. Giannini Found. Inf. Ser. No. 86-1.
Passof, P.C., W.J. Clawson, and E.L. Fitzhugh. 1985. Preliminary guidelines for managing California's hardwood rangelands. Univ. California Div. Agr. and Nat. Resour. Pub. 21413.

Sumner, E.L., Jr. 1935. A life history study of the California quail, with recommendations for its conservation and management. Calif. Fish and Game 21275-342.

United States Depurtment of Agriculture. 1972. The nation's range resources-A forest-range environmental study. Forest. Res. Rep. 19. Gov. Print. Off., Washington, D.C. $\# 0101-237$. 